\title{
Inhibition of Proliferation of Breast Cancer Cells MCF7 and MDA-MB-231 by Lipophilic Extracts of Papaya (Carica papaya L. var. Maradol) Fruit
}

\author{
Laura E. Gayosso-García Sancho ${ }^{*}$, Elhadi M. Yahia², Pablo García-Solís ${ }^{3}$, \\ Gustavo A. González-Aguilar ${ }^{*}$ \\ ${ }^{1}$ Jefatura de Nutrición Humana, Universidad Estatal de Sonora, Hermosillo, México \\ ${ }^{2}$ Facultad de Ciencias Naturales, Universidad Autónoma de Querétaro, Querétaro, México \\ ${ }^{3}$ Facultad de Medicina, Universidad Autónoma de Querétaro, Querétaro, México \\ ${ }^{4}$ Coordinación de Tecnología de Alimentos de Origen Vegetal, Centro de Investigación en Alimentación y \\ Desarrollo, A.C., Hermosillo, México \\ Email: *laura.gayosso@ues.mx,, gustavo@ciad.mx
}

Received 19 August 2014; revised 12 September 2014; accepted 20 October 2014

Copyright (C) 2014 by authors and Scientific Research Publishing Inc.

This work is licensed under the Creative Commons Attribution International License (CC BY).

http://creativecommons.org/licenses/by/4.0/

(c) (i) Open Access

\section{Abstract}

Several epidemiological studies have suggested that carotenoids have antineoplasic activities. The objective of this study was to determine the antiproliferative effect of rich carotenoid lipophilic extracts of papaya fruit pulp (Carica papaya L., cv Maradol) in breast cancer cells, MCF-7 (estrogen receptor positive) and MDA-MB-231 (estrogen receptor negative), and in non-tumoral mammary epithelial cells MCF-12F. Antiproliferative effect was evaluated using the methylthiazolydiphenyltetrazolium bromide (MTT) assay and testing lipophilic extracts from different papaya fruit ripening stages (RS1, RS2, RS3, RS4), at different times $(24,48$ and $72 \mathrm{~h})$. Papaya lipophilic extracts do not inhibit cell proliferation of MCF-12F and MDA-MB-231 cells. However, MCF-7 cells showed a significant reduction in proliferation at $72 \mathrm{~h}$ with the RS4 papaya extract. Results suggested that lipophilic extracts had different action mechanisms on each type of cells and therefore, more studies were required to elucidate such mechanisms.

\section{Keywords}

Carica papaya, Antiproliferative Activity, Breast Cancer, Carotenoids

\footnotetext{
${ }^{*}$ Corresponding authors.

How to cite this paper: Gayosso-Garcia Sancho, L.E., Yahia, E.M., García-Solís, P. and González-Aguilar, G.A. (2014) Inhibition of Proliferation of Breast Cancer Cells MCF7 and MDA-MB-231 by Lipophilic Extracts of Papaya (Carica papaya L. var. Maradol) Fruit. Food and Nutrition Sciences, 5, 2097-2103. http://dx.doi.org/10.4236/fns.2014.521222
} 


\section{Introduction}

Cancer caused 8.2 million deaths in 2012, according to the Global Cancer Statistics, from which 521,000 were breast cancer related, and it is forecasted that by 2030 this number will increase to 22 million [1]. Recent research studies established that if oxidative stress (generated by an overproduction of free radicals) is excessive, and DNA repairing systems are surpassed, a mutagenesis and carcinogenesis could be promoted [2].

Several studies have suggested that the consumption of fruits and vegetables could reduce the risk of many chronic diseases, and have a protective effect against certain types of cancer [3]. In response to this, the US Department of Health and Human Services [4] is has recommended to increase the consumption of fruits and vegetables from 5 to 13 portions a day. The beneficial effect of diets rich in fruits and vegetables is attributed mainly to bioactive components (carotenoids, phenolic compounds, flavonoids, vitamins $\mathrm{C}$ and $\mathrm{E}$ ) that provide antioxidant, antimicrobial and antiproliferative properties [5]-[7]. A high consumption of carotenoids could be associated with the reduction of the risk of breast cancer, because these types of compounds show several biological activities, from which the promotion of apoptosis in transformed cells stands out [8]. These antioxidants induce cell differentiation, repair damaged DNA, inhibit gene mutation, and activate tumor-suppressive genes [9]. Additionally, a panel of experts concluded that an inverse association of carotenoids with the risk of breast cancer is possible due to their antioxidant properties [10].

Mexico is the biggest exporter of papaya [11], a climacteric tropical fruit that has diverse bioactive components (BC) that give the fruit several antioxidant properties [12] [13]. This fruit is especially rich in carotenoids, such as lycopene, $\beta$-cryptoxantine and $\beta$-carotene [12] [14]. Most of the research done in different cell lines have focused on the utilization of isolated doses of several BCs, and have not considered the importance of employing a mix of these, like those naturally occuring in the fruit, in order to determine the beneficial effect on health of a diet rich in fruits and vegetable. The objective of this study was to evaluate the antiproliferative effect of lipophilic extract (carotenoids) of "Maradol” papaya fruit on breast cancer cell MCF-7 (estrogen receptor positive) and MDA-MB-231 (estrogen receptor negative) and non-tumoral breast epithelial cells MCF-12F for possible use as chemopreventive agent.

\section{Materials and Methods}

\subsection{Plant Material}

Fresh papaya fruit (Carica papaya L., cv. Maradol) was obtained from a local market in Hermosillo, Sonora, Mexico. Fruit were selected for uniformity in size, color, level of external ripeness, and were divided into 4 lots based on four ripeness stages: RS1 (fruit with 0\% - 25\% skin yellow color); RS2 > 25\% to 50\%; RS3 > 50\% to $75 \%$; and RS4 > 75\% to $100 \%$.

\subsection{Papaya Extracts Preparation}

Lipophilic extracts were prepared as described previously by Yahia et al. [15] and Gayosso García-Sancho et al. [16]. Papaya flesh dry sample (0.5 g) was briefly homogenized in $10 \mathrm{~mL}$ of hexane:dichloromethane (1:1, v/v), using an Ultra Turrax ${ }^{\circledR}$ T25 basic homogenizer (IKA Works, Willmington, NC); then it was centrifuged at 9000 $\mathrm{g}$ for 10 minutes at $5^{\circ} \mathrm{C}$. The organic phase was separated and the procedure was repeated three times. For alkaline hydrolysis, $10 \mathrm{~mL}$ of methanolic $\mathrm{KOH} 40 \%\left(1: 1\right.$, v/v) were added to extracts for 1 hour at $50^{\circ} \mathrm{C}$, and stirred at $100 \mathrm{rpm}$ in a stirring bath set. After saponification, $10 \mathrm{~mL}$ of $10 \%$ sodium sulfate were added for phase separation, and the extracts were left for 1 hour in the dark at room temperature. Extracts were evaporated in a Rotovapor $^{\circledR}$ (Büchi Labortechnik AG, Flawil, Switzerland), at $30^{\circ} \mathrm{C}$ in a Buchi low pressure evaporator. Samples were re-suspended in $2 \mathrm{~mL}$ acetone, filtered through nylon membrane of $0.45 \mu \mathrm{m}$ of pore size (Millipore Corp., Bedford, MA), and stored at $-78^{\circ} \mathrm{C}$ until their utilization in cell culture.

\subsection{Cell Culture}

The non-tumoral breast epithelial cell line MCF-12F and breast cancer cell lines MCF-7 (estrogen receptor positive) and MDA-MB-231 (estrogen receptor negative) were kindly supplied by Dr C. Aceves (Instituto de Neurobiología, UNAM, Queretaro, Mexico). Cells were grown in Dulbecco’s modified Eagle’s medium (DMEM), supplemented with 5\% (v/v) fetal bovine serum (FBS, Sigma-Aldrich, St Louis, MO, USA), 100 U/ml penicillin, 
and $100 \mathrm{mg} / \mathrm{ml}$ streptomycin (basal medium), and then were incubated at $37^{\circ} \mathrm{C}$ in a $95 \%$ humidified atmosphere containing $5 \% \mathrm{CO}_{2}$.

\subsection{Determination of the Antiproliferative Activity}

The antiproliferative activity of papaya extracts at four different stages of ripeness (RS) in MCF-12F and in MCF-7 and MDA-MB 231 cells, was measured using 3-(4, 5-dimethylthiazol-2-yl)-2, 5-diphenyltetrazolium bromide (MTT) assay, as previously described [13], with some modifications. Cells were seeded at a density of 5000 cells/well, in 96-well flat-bottomed plates, in a final volume of $100 \mu l$, and incubated for 24 hours prior to the addition of lipophilic extracts of papaya. Then, $100 \mu \mathrm{l}$ of fresh medium were added at carotenoid concentrations of 0.92, 1.61, 2.08 and $3.27 \mathrm{mg} / \mathrm{mL}$, which correspond to RS1, RS2, RS3, and RS4, respectively. The kind and concentrations of carotenoids in each papaya extract are shown in Table 1. Acetone at non-toxic level (0.5\%) was used in the medium as a control. The kind and concentrations of carotenoids in the extracts were determined previously according to García-Solís et al. method [17], using concentrations of lipophilic extracts of $0.5 \%, 1 \%$ and $2 \%(\mathrm{v} / \mathrm{v})$, then cells were incubated for 24,48 and $72 \mathrm{~h}$. As a positive control in each essay a treatment with $500 \mathrm{nM}$ thapsigargin was included, which is considered to be a strong apoptotic inducer and inhibitor of cell proliferation [18]. Thapsigargin was dissolved in dimethyl sulfoxide (DMSO), which represents $0.1 \%(\mathrm{v} / \mathrm{v})$ of the culture medium, and solvent controls were also included. MTT solution at $5 \mathrm{mg} / \mathrm{ml}$ was dissolved in $1 \mathrm{~mL}$ of phosphate-buffered saline (PBS); $20 \mu \mathrm{l}$ of it was added to each of the 96 wells at 24, 48 and 72 hours of incubation, at $37^{\circ} \mathrm{C}$ for 1 hour. The solution in each well containing MTT, media and dead cells was removed by suction, and formazan crystals were dissolved with $100 \mu$ DMSO in each well. DMSO was used as solvent control. The plates were then shaken and the absorbance was measured using a micro plate reader (Multiskan Ascent ${ }^{\circledR}$, Thermo electron corporation), at $610 \mathrm{~nm}$. Cell proliferation was determined using the average of absorbance units reading from the wells and was expressed as percentage with respect to the control (untreated cells). At least three replications for each sample were used to determine cell proliferation. All experiments were performed at least in duplicate.

\subsection{Statistical Analysis}

Comparisons of mean values of control and treatment cells were made using ANOVA, followed by Duncan's test, between control and each treatment group. The statistical significance of difference $(P<0.05)$ for the treatment groups was determined relative to their respective control group, using the statistical software SAS version 8.0 (SAS Inst. Inc. Cary, NC, USA). At least three replications for each sample were used to determine cell proliferation, and all experiments were performed at least in duplicate.

\section{Results and Discussion}

The effect of carotenoids from lipophilic extracts of "Maradol” papaya, at four stages of ripeness (RS1, RS2, RS3 and RS4), on the proliferation of non-tumorogenic MCF-12F breast epithelial cells, as well as the effect on MCF-7 and MDA-MB-231 breast cancer cells is shown in Figure 1. In MCF-12F cells it was observed that papaya lipophilic extracts did not inhibit cell proliferation after $72 \mathrm{~h}$ of treatment, which suggests that the main component of extracts, carotenoids, did not affect cell growth in a normal breast epithelium. Other studies observed that when using $\beta$-carotene a similar behavior was obtained; suggesting that carotenoids have a protective effect on normal cells by facilitating their growth [19]. This result suggests that MCF-12F cells could be a

Table 1. Contents of the main carotenoid compounds identified in the pulp of "Maradol” papaya.

\begin{tabular}{cccc}
\hline Ripeness Stage (RS) & Lycopene (mg/100 g DW) & $\beta$-Cryptoxanthin (mg/100g DW) & $\beta$-Carotene (mg/100 g DW) \\
\hline 1 & $0.524^{\mathrm{a}}$ & $0.331^{\mathrm{a}}$ & $0.387^{\mathrm{a}}$ \\
2 & $2.48^{\mathrm{b}}$ & $0.558^{\mathrm{b}}$ & $0.409^{\mathrm{a}}$ \\
3 & $2.78^{\mathrm{b}}$ & $0.794^{\mathrm{c}}$ & $0.441^{\mathrm{a}}$ \\
4 & $4.23^{\mathrm{c}}$ & $1.295^{\mathrm{d}}$ & $0.752^{\mathrm{b}}$ \\
\hline
\end{tabular}

Different letter in the same column indicate significant differences $(P \leq 0.05)$. 
good model to explore the effect of papaya fruit carotenoids on initiating carcinogenesis of breast cancer.

We have reported on the physiological and biochemical changes that occur during the ripening of "Maradol" papaya [12]; but the effect of this process on the potential antiproliferative activity of the mix of carotenoid compounds in the fruit is not known; which is why we have decided to investigate the effect of carotenoids from lipophilic extracts of "Maradol" papaya, at four stages of ripeness on the proliferation of non-tumorogenic MCF-12F breast epithelial cells, as well as the effect on MCF-7 and MDA-MB-231 breast cancer cells. Cancer, one of the main causes of mortality, originates as the result of the interaction of various genetic, physical, chemical and biological factors that transform cells until they become malignant tumors [20]. Tumors are usually localized, but can disseminate to other organs, originating metastasis [1]. According to the Mexican Ministry of Health, breast cancer has become the main cause of death in Mexican women 25 years of age and older since 2006, replacing uterine cancer [21].

The effects of papaya extracts on MCF-7 cell line, which is the most utilized for studies of estrogen receptorpositive breast cancer [22], are shown in Figure 2. Cell proliferation levels were lower with RS3 and RS4 (67.3\% and 66.8\%, respectively), while proliferation has higher with RS1, and RS2 (77.3\% and 75.5\%, respectively), showing that lipophilic extracts of papaya reduced significantly the proliferation of MCF-7 cells, being generally more effective at $72 \mathrm{~h}$ of incubation . These results, which ranged from $22 \%$ and $33 \%$ in the inhibition of cell proliferation, could be related with the concentration of carotenoids contained in the extracts. In a preliminary study [12] we identified and quantified the three main carotenoids found in "Maradol" papaya at different stages of ripeness (Table 1), been lycopene, $\beta$-criptoxantine and $\beta$-carotene. This might indicate that bioactive

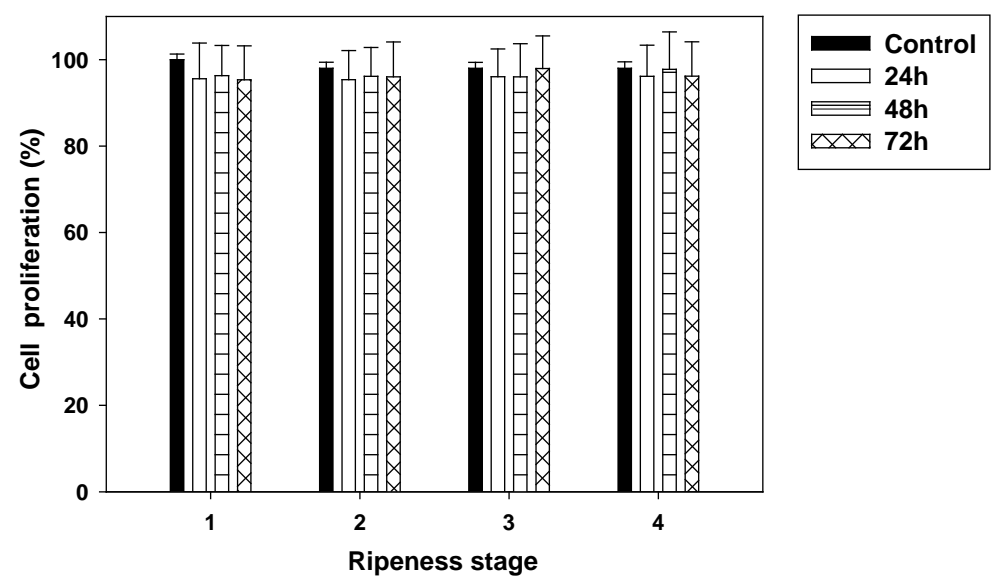

Figure 1. Effect of papaya extracts on cell proliferation in MCF-12F cells after 24,48 and $72 \mathrm{~h}$.

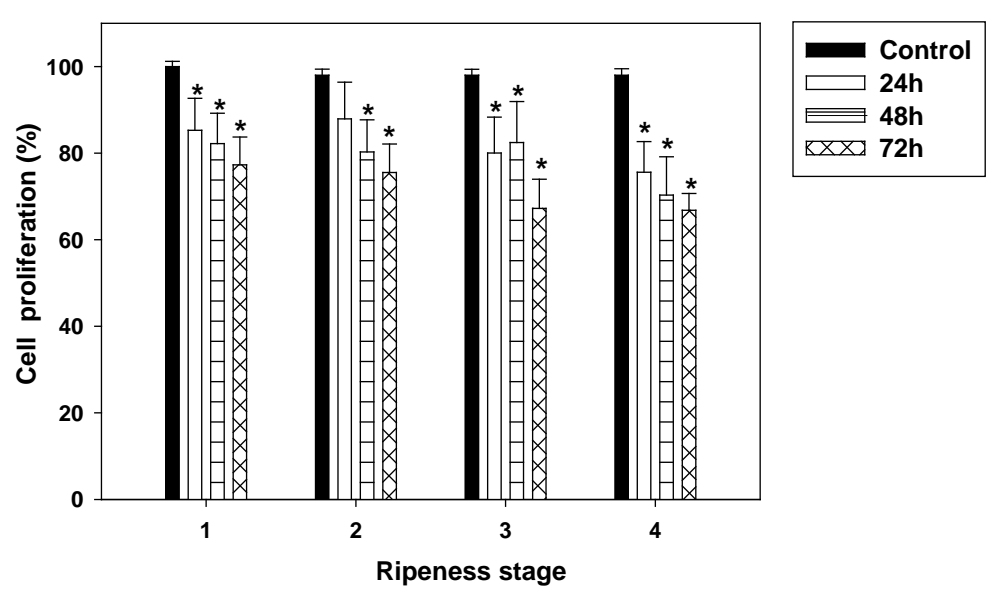

Figure 2. Effect of papaya extracts on cell proliferation in MCF-7 cells after 24, 48 and $72 \mathrm{~h}$. 
compounds of the extracts could act in a synergetic manner with other anticarcinogenic compounds, giving as a result an enhanced antiproliferative activity, hence, a greater health benefit [23]. Previous studies have shown the inhibition effect of carotenoids on this type of cancer cells: García Solís et al. [17] found that papaya extract had a significant inhibitory effect on proliferation of MCF-7 cells and Cui et al. [24] observed that $\beta$-Carotene induced apoptosis in MCF-7 cells.

Carotenoids regulate cell growth, inhibit the growth of malignant cells, and promote apoptosis in transformed cells [24]. Additionally, some individual carotenoids, such as $\beta$-carotene and lycopene, have inhibited the growth of MCF-7 cells in vitro [25]. The antiproliferative effect of aqueous extracts of 14 plant foods on the MCF-7 breast cancer cell line was evaluated [17], and only papaya extract, rich in $\beta$-carotene (dose of 0.85 $\mathrm{mg} / \mathrm{mL}$ ) after $72 \mathrm{~h}$ of treatment, significantly decreased cell proliferation. On the other hand, a study performed in a group of women who followed a diet rich in carotenoids, observed that the survival probability increased during the first stages of breast cancer [26]. Other studies have shown the inhibiting effect of various compounds on MCF-7 cancer cells, especially during the early stages of carcinogenesis, through antioxidant and antinflammatory routes; the induction of apoptosis; the halting of cell cycle in early tumors, and in tumors with greater development; and the potential blocking of progression and metastasis, through the expression of genes that suppress tumors [19]. Though, carotenoids present in fruits and vegetables show several beneficial properties in humans (especially lycopene and $\beta$-carotene), such as antioxidant activity, increased intercellular communications, modulation of insulin-like growth factor-1 (IGF1), inhibition of cell proliferation, and enhancement of immune system function [27].

We have also explored the effect papaya extracts in the proliferation of estrogen receptor-negative breast cancer cell line MDA-MB-231 (Figure 3). MDA-MB-231 cells did not show any significant inhibitory effect in their proliferation in frank contrast with the effect on MCF-7 cells. Moreover, a slight non-significant cell proliferation increment was observed with extract RS1 after 48 and $72 \mathrm{~h}$ of treatment and this behavior changed in RS2 to RS4 extracts MDA-MB-231 cells with negative response to estrogens are considered a more de-differrentiated form than MCF-7 cells, therefore they are considered more aggressive [28], and this could explain why their inhibition was not significant. Our results coincided with those obtained by other researchers [29], where the use of retinoids and $\beta$-carotene had no inhibitory effect on this type of cells. In a study performed with anoikis-resistant MDA-MB-231 cells [30], it was found that this type of cells can turn refractory to several chemotherapeutic agents, due to a gene overexpression related to nuclear factor kappa $\mathrm{B}(N F-\kappa B)$, which is one of the vital transcriptional cell factors, giving as a result greater aggressive behavior and greater cell resistance. Nevertheless, a possible way to reduce cell proliferation MDA-MB-231 could be the use of a mix of carotenoids, which have biological mechanisms that still have not been completely elucidated; then it would be necessary to focus on determining their molecular mechanism on this type of cell lines.

\section{Conclusion}

Papaya (Carica papaya L. var Maradol) is a tropical fruit that has significant antioxidative properties. Our re-

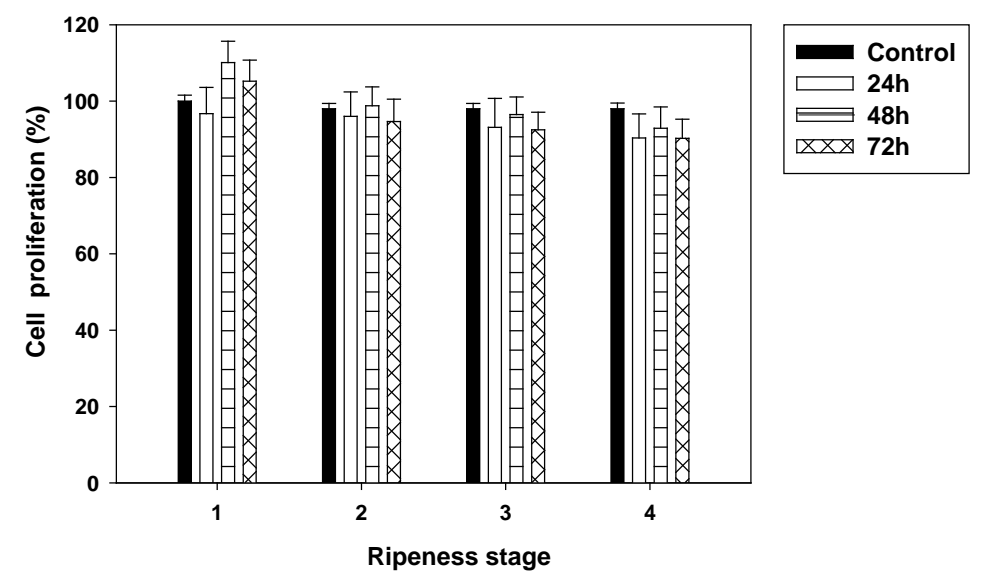

Figure 3. Effect of papaya extracts on cell proliferation in MDA-MB-231 cells after 24,48 and $72 \mathrm{~h}$. 
sults showed that carotenoids present in ripened papaya could contribute to the reduction of the proliferation of MCF-7 breast cancer cells. Although the relationship between the consumption of carotenoids and breast cancer is not completely elucidated, it is necessary to continue with this type of research to be able to determine the mechanism by which these types of compounds are able to provide a beneficial effect to human health.

\section{References}

[1] World Health Organization (2014) The World Health Report. http://www.who.int/whosis/whostat/en/index.html

[2] Lee, J., Koo, N. and Min, D.B. (2004) Reactive Oxygen Species, Aging, and Antioxidative Nutraceuticals. Comprehensive Review Food Science and Food Safety, 3, 21-33. http://dx.doi.org/10.1111/j.1541-4337.2004.tb00058.x

[3] Yahia, E.M. (2010) The Contribution of Fruit and Vegetable Consumption to Human Health. In: de la Rosa, L.A., Alvarez-Parrilla, E., Gonzalez-Aguilar, G.A., Eds., Fruit and Vegetable Phytochemicals, Wiley-Blackwell, Iowa, 3-51.

[4] US Department of Agriculture, US Department of Health and Human Services (USDA/HHS) (2010) 2005 Dietary Guidelines Advisory Committee Report. http://www.health.gov/dietaryguidelines.gov

[5] Gonzalez-Aguilar, G.A., Celis, J., Sotelo-Mundo, R.R., De La Rosa, L.A., Rodrigo-García, J. and Alvarez-Parrilla, E. (2008) Physiological and Biochemical Changes of Different Fresh-Cut Mango Cultivars Stored at $5^{\circ} \mathrm{C}$. International Journal of Food Science and Technology, 43, 91-101. http://dx.doi.org/10.1111/j.1365-2621.2006.01394.x

[6] McEligot, A.J., Yang, S. and Meyskens Jr., F.L. (2005) Redox Regulation by Intrinsic Species and Extrinsic Nutrients in Normal and Cancer Cells. Annual Review of Nutrition, 25, 261-295. http://dx.doi.org/10.1146/annurev.nutr.25.050304.092633

[7] Borek, C. (2004) Dietary Antioxidants and Human Cancer. Integrative Cancer Therapies, 3, 333-341. http://dx.doi.org/10.1177/1534735404270578

[8] Sumantran, V.N., Zhang, R., Lee, D.S. and Wicha, M.S. (2000) Differential Regulation of Apoptosis in Normal versus Transformed Mammary Epithelium by Lutein and Retinoic Acid. Cancer Epidemiology Biomarkers \& Prevention, 9, 257-263.

[9] Rock, C.L. (2002) Carotenoids and Cervical, Breast, Ovarian, and Colorectal Cancer. Pure and Applied Chemistry, 74, 1451-1459. http://dx.doi.org/10.1351/pac200274081451

[10] Krinsky, N.I. and Johnson, E.J. (2005) Carotenoid Actions and Their Relation to Health And Disease. Molecular Aspects of Medicine, 26, 459-516. http://dx.doi.org/10.1016/j.mam.2005.10.001

[11] Propapaya (2013) http://www.propapaya.org

[12] Gayosso-García Sancho, L.E., Yahia, E.M., Martínez-Téllez, M.A. and González-Aguilar, G.A. (2010) Effect of Maturity Stage of Papaya Maradol on Physiological and Biochemical Parameters. American Journal of Agricultural and Biological Sciences, 5, 194-203. http://dx.doi.org/10.3844/ajabssp.2010.194.203

[13] Corral-Aguayo, R.D., Yahia, E.M., Carrillo-Lopez, A. and González-Aguilar, G. (2008) Correlation between Some Nutritional Components and the Total Antioxidant Capacity Measured with Six Different Assays in Eight Horticultural Crops. Journal of Agricultural and Food Chemistry, 56, 10498-10504. http://dx.doi.org/10.1021/jf801983r

[14] Rivera-Pastrana, D.M., Yahia, E.M. and Gonzalez-Aguilar, G. (2010) Phenolic and Carotenoid Profiles of Papaya Fruit (Carica papaya L.) and Their Contents under Low Temperature Storage. Journal of the Science of Food \& Agriculture, 90, 2358-2365. http://dx.doi.org/10.1002/jsfa.4092

[15] Yahia, E.M., Soto-Zamora, G., Brecht, J.K. and Gardea, A. (2007) Postharvest Hot Air Treatment Effects on the Antioxidant System in Stored Mature-Green Tomatoes. Postharvest Biology and Technology, 44, 107-115.

http://dx.doi.org/10.1016/j.postharvbio.2006.11.017

[16] Gayosso-García Sancho, L.E., Yahia, E.M. and González-Aguilar, G.A. (2011) Identification and Quantification of Phenols, Carotenoids and Vitamin C from Papaya (Carica Papaya L., cv. Maradol) Fruit Determined by HPLC-DADMS/MS ESI. Food Research International, 44, 1284-1291. http://dx.doi.org/10.1016/j.foodres.2010.12.001

[17] García-Solís, P., Yahia, E.M., Morales-Tlalpan, V. and Diaz-Muñoz, M. (2009) Screening of Antiproliferative Effect of Aqueous Extracts of Plant Foods Consumed in Mexico on the Breast Cancer Cell Line MCF-7. International Journal of Food Sciences and Nutrition, 26, 32-46. http://dx.doi.org/10.1080/09637480802312922

[18] Jackisch, C., Hahm, H.A., Tombal, B., McCloskey, D., Butash, K., Davidson, N.E. and Denmeade, S.R. (2000) Delayed Micromolar Elevation in Intracellular Calcium Precedes Induction of Apopoptosis in Thapsigargin-Treated Breast Cancer Cells. Clinical Cancer Research, 6, 2844-2850.

[19] Thangaiyan, R. and Anupam, B. (2009) Terpenoids and Breast Cancer Chemoprevention. Breast Cancer Research and Treatment, 115, 223-239. http://dx.doi.org/10.1007/s10549-008-0118-y

[20] Musa-Veloso, K., Card, J.W., Wong, A.W. and Cooper, D.A. (2009) Influence of Observational Study Design on the 
Interpretation of Cancer Risk Reduction by Carotenoids. Nutrition Reviews, 67, 527-545. http://dx.doi.org/10.1111/j.1753-4887.2009.00225.x.

[21] Knaul, F.M., Nigenda, G., Lozano, R., Arreola-Ornelas, H., Langer, A. and Frenk, J. (2009) Cáncer de mama en México: Una prioridad apremiante. Salud Pública de México, 51, 335-344. http://www.scielo.org.mx/scielo.php?script=sci arttext\&pid=S0036-36342009000800026\&lng=es\&tlng=es.

[22] Simstein, R., Burow, M., Parker, A., Weldon, C. and Beckman, B. (2003) Review Apoptosis, Chemoresistance, and Breast Cancer: Insights from the MCF-7 Cell Model System. Experimental Biology and Medicine, 228, 995-1003.

[23] Yang, J. and Liu, R. (2009) Synergistic Effect of Apple Extracts and Quercetin 3- $\beta$-D-Glucoside Combination on Antiproliferative Activity in MCF-7 Human Breast Cancer Cells in Vitro. Journal of Agricultural of Food Chemistry, 57, 8581-8586. http://dx.doi.org/10.1021/jf8039796.

[24] Cui, Y., Lu, Z., Bai, L., Shi, Z., Zhao, W.E. and Zhao, B. (2007) $\beta$-Carotene Induces Apoptosis and Up-Regulates Peroxisome Proliferator-Activated Receptor $\gamma$ Expression and Reactive Oxygen Species Production in MCF-7 Cancer Cells. European Journal of Cancer, 43, 2590-2601. http://dx.doi.org/10.1016/j.ejca.2007.08.015

[25] Prakash, P., Russell, R.M. and Krinsky, N.I. (2001) In Vitro inhibition of Proliferation of Estrogen-Dependent and Estrogen-Independent Human Breast Cancer Cells Treated with Carotenoids or Retinoids. The Journal of Nutrition, 131, 1574-1580.

[26] Rock, C.L., Natarajan, L., Pu, M., Thomson, C.A., Flatt, S.W., Caan, B.J., Gold, E.B., Al-Delaimy, W.K., Newman, V. A., Hajek, R.A., Stefanick, M.L. and Pierce, J.P. (2009) Longitudinal Biological Exposure to Carotenoids Associated with Breast Cancer-Free Survival in the Women's Healthy Eating and Living Study. Cancer Epidemiology, Biomarkers \& Prevention, 18, 486-494. http://dx.doi.org/10.1158/1055-9965.EPI-08-0809.

[27] Yahia, M.E. and Ornelas-Paz, J.J. (2010) Chemistry, Stability and Biological Actions of Carotenoids. In: de la Rosa L. A., Alvarez-Parrilla, E. and Gonzalez-Aguilar, G.A., Eds., Fruit and Vegetable Phytochemicals, Wiley-Blackwell, Ames, 177-222.

[28] Ross, D.T. and Perou, C.M. (2001) A Comparison of Gene Expression Signatures from Breast Tumors and Breast Tissue Derived Cell Lines. Disease Markers, 17, 99-109. http://dx.doi.org/10.1155/2001/850531

[29] Prakash, P., Krinsky, N.I. and Russell, R.M. (2000) Retinoids, Carotenoids, and Human Breast Cancer Cell Cultures: A Review of Differential Effects. Nutrition Reviews, 58, 170-176. http://dx.doi.org/10.1111/j.1753-4887.2000.tb01856.x

[30] Yu, J., Han, W., Kim, J., Lee, J., Ko, E., Kim, E., Moon, H. and Noh, D. (2009) Anoikis-Resistant MDA-MB-231 Cells: Characteristics and Pathway Analysis. Cancer Research, 69, 2062. http://dx.doi.org/10.1158/0008-5472.SABCS-2062 
Scientific Research Publishing (SCIRP) is one of the largest Open Access journal publishers. It is currently publishing more than 200 open access, online, peer-reviewed journals covering a wide range of academic disciplines. SCIRP serves the worldwide academic communities and contributes to the progress and application of science with its publication.

Other selected journals from SCIRP are listed as below. Submit your manuscript to us via either submit@scirp.org or Online Submission Portal.
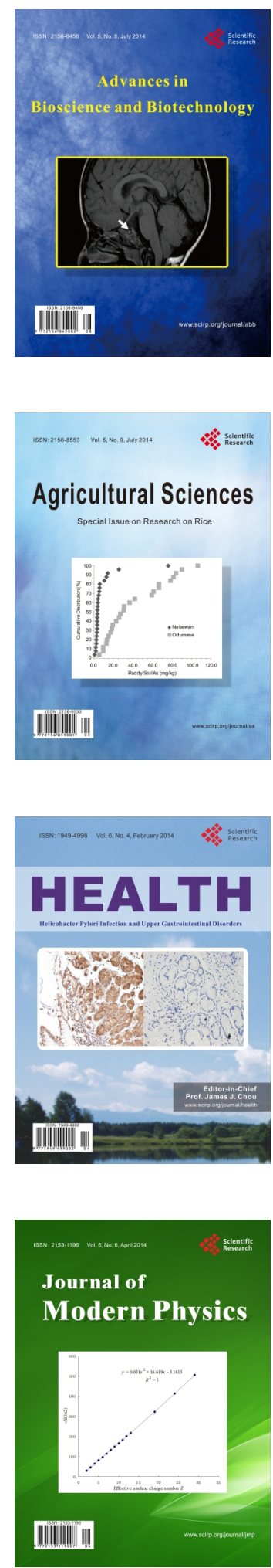
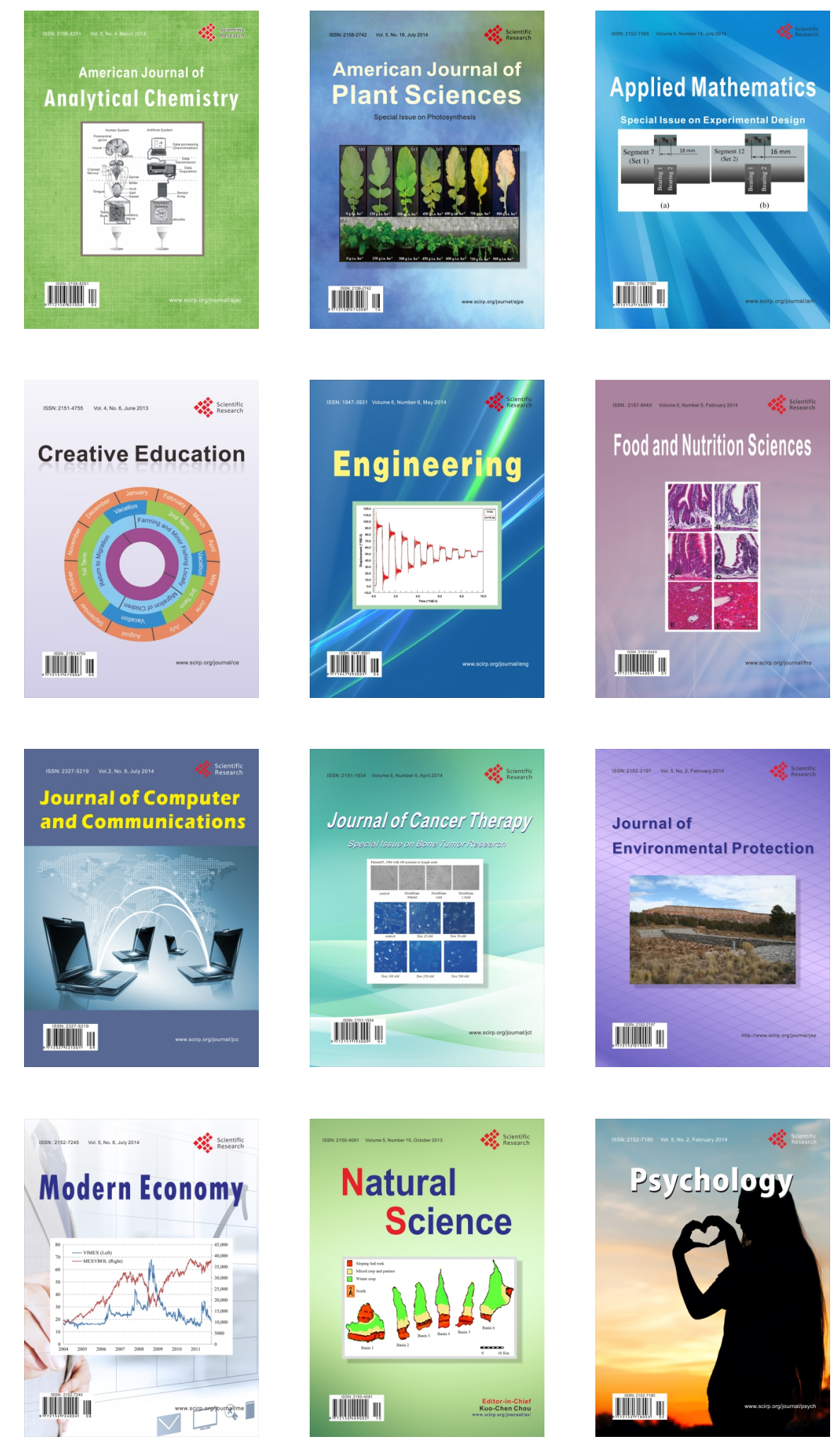